\section{School environment and physical activity in children and adolescents: systematic review}

\section{Ambiente escolar e atividade física em crianças e adolescentes: revisão sistemática}

\author{
Alan G Knuth ${ }^{1,2}$
}

Pedro C Hallal ${ }^{2}$

\begin{abstract}
The aim of this study was to identify, discuss and summarize findings from articles on the association between characteristics of the school environment and physical activity in children and adolescents. We followed the PRISMA guidelines for systematic reviews. Articles were identified in PubMed. The main inclusion criteria were: (a) studies with children and adolescents - studies with preschool children only were excluded because they were covered in a recent review; (b) physical activity as the outcome; (c) school environment characteristics as the exposure variable. Outcome variables were heterogeneous across the 13 studies, including recess physical activity practice, extracurricular sports practice, Physical Education classes and total physical activity. Half of the studies used objective physical activity measures. The evaluation of school environments was again heterogeneous, ranging from checklists of spaces, satellite photos and interviews with school teachers and principals comprising sociocultural dimensions of the environment, policies and $\mathrm{PE}$ classes, but mainly measures of the built environment. No definitive conclusion about the influence of school environment on physical activity can be drawn due to the heterogeneity across studies, settings dimension assessed and the lack of prospective data. However, several features such as improvements in playgrounds, health promotion policies at school, and positive perceptions of the school environment seem to be associated with increased physical activity among children and adolescents.
\end{abstract}

\section{Keywords}

School, physical activity, youth, environment

\section{Resumo}

O objetivo deste estudo foi identificar, discutir e sumarizar os achados sobre a associação entre características do ambiente escolar e atividade física em crianças e adolescentes. Foi utilizado o guia PRIS$M A$ para revisões sistemáticas. Artigos foram buscados na PubMed. Os principais critérios de inclusão foram: (a) estudos com crianças e adolescentes - estudos apenas com pré-escolares foram excluídos em função de uma recente revisão com este grupo; (b) atividade física como desfecho; (c) características do ambiente escolar como exposição. Os desfechos avaliados foram bastante heterogêneos entre os 13 estudos, desde atividade física no recreio, atividades extracurriculares, aula de educação física até atividade física total. Metade dos estudos utilizou medidas objetivas de atividade física. O ambiente escolar, também heterogêneo, foi avaliado a partir de listagem dos espaços físicos, fotos de satélite, entrevistas com diretores e professores, politicas e aulas de educação física, com predominio para medidas do ambiente construído. Não foi possivel ser conclusivo sobre a influência do ambiente escolar na atividade física, em função da heterogeneidade entre os estudos, dimensão ambiental avaliada e carência de dados prospectivos. Por outro lado, diversos atributos como melhorias nos parquinhos, politicas de promoção da saúde e percepções positivas do ambiente escolar parecem se relacionar com maior participação em atividades físicas em crianças e adolescentes.

\section{Palavras-chave}

Escola, Atividade física, Jovens, Ambiente.
Rev Bras Ativ Fis Saúde p. 463-473 DOI: http://dx.doi.org/10.12820/2317$1634.2012 \mathrm{v} 17 \mathrm{n} 6 \mathrm{p} 463$

1 Federal University of Rio Grande, Rio Grande, RS, Brazil

2 Program in Epidemiology, Federal University of Pelotas, Pelotas, RS, Brazil 


\section{INTRODUCTION}

Physical activity is determined by multiple levels of influencing factors, including physiological and social factors that affect the individual directly, and physical and sociocultural influences through the environment, in an ecological perspective $e^{1,2}$. Importantly, the determinants of physical activity vary according to age. Among children and adolescents, a key part of this chain is the school environment, because youth spend several hours per day in this setting. At school, young people are exposed to the physical education classes and other kinds of physical activities, they interact with teachers and peers and remain at the school setting for many years. During the school years, people adopt different behaviors and the understanding of this context is essential under a public health perspective. Other environments, such as the household and its surrounding neighborhood ${ }^{3}$ are also relevant at determining children and adolescents' behavior.

Within the school environment, several strategies are used to promote active lifestyles based on the principles of ecological models applied to active living ${ }^{2}$. This idea suggests that different environments tend to mix up (the built with the perceived, the natural, the sociocultural and informational), and this complex interaction makes it difficult to disentangle different features of the environment. When we look at school the studies focusing on improvements in Physical Education (PE) classes, the creation of friendly environments towards physical activity, continued capacity building for $\mathrm{PE}$ teachers, material and equipment provision, access to the school space in alternative hours, among others, are examples of features of the environment investigated. These varying features of the environment concept make it difficult for the studies to estimate the single influence of one of the environment dimensions on physical activity levels. All these possibilities are heterogeneously distributed across schools, particularly in places where no large scale intervention programs exist. More importantly, however, is the fact that school environments explain a significant proportion of the variability in children's physical activity and sedentary behaviors. ${ }^{4}$

Based on this scenario, diagnosing aspects of the school environments is an essential tool for understanding children and adolescents' behaviors and ultimately for proposing interventions. School environments are not important only for physical activity, but also in terms of obesity prevention, safety, hygiene, community and parental participation, among other topics. Therefore, every six years, the Center for Disease Control and Prevention (CDC) conducts the School Health Policies and Programs Study (SHPPS) that includes a set of questions on school environments. ${ }^{5}$ In Brazil, the Ministry of Health launched the Pesquisa Nacional de Saúde do Escolar (PeNSE) ${ }^{6}$, which intends to improve our understanding about indicators of the school environment and their influence on youth's life. In both these examples, however, there is a clear emphasis on the evaluation of features of the outdoor built environment, thus suggesting that the evaluation of school environments is still a literature gap ${ }^{7}$.

The purpose of this systematic review was to identify, discuss and summarize findings from articles on the association between school environment and physical activity, by focusing on studies including youth from grades 1 to 12 . We also present the most frequently used measures of the school environment and physical activity, as well as identify gaps in the existing literature. 


\section{METHODS}

Our systematic review was carried out following the PRISMA guidelines. ${ }^{8}$ Articles were identified in PubMed (http://www.ncbi.nlm.nih.gov/pubmed). The search was carried out using a combination of physical activity ("physical activity" OR "motor activity" OR fitness OR exercise OR "recreational activities") AND school environment-related (environment $O R$ "outdoor environment" OR "environment design" OR "physical environment" OR "environmental health" OR "school environment" OR "preschool environment" OR "recreational environment") keywords, and was restricted to studies with humans. The inclusion criteria were: (a) studies with children and adolescents - studies with preschool children only were excluded because they were covered in a recent review; ${ }^{4}$ (b) physical activity should be the outcome variable regardless the measure of physical activity used (we included the only article identified that used measures of physical fitness instead of physical activity); (c) the school environment should be the exposure variable, again regardless the dimension of environment ${ }^{2}$ (built/perceived, natural, informational or socio/ cultural). The systematic search was restricted to articles in English, Spanish and Portuguese. In all phases, articles were read by the first author, and in case of doubts, the second author had an independent review and a decision was taken by the two authors together. The review process was finalized on October 26th, 2010.

We will use the term 'school environment' throughout this article, although we acknowledge this is not a unique concept, as discussed by Trost and colleagues ${ }^{4}$ and the ecological models applied to the physical activity field. For example, we understand that PE classes, extracurricular sports activities and school policies are part of the same concept. By using this ecological framework, we acknowledge that physical, informational, natural and social/cultural environments are intrinsically related to each other.

\section{RESULTS}

In the identification phase, 11,680 articles were detected. In the screening phase, based on the reading of titles, 63 articles were considered as potentially relevant. We later evaluated the abstracts of these articles and identified 31 that could potentially fulfill our inclusion criteria. In the eligibility phase, all articles were read, and the reference lists were examined. As a result, 13 studies fulfilling our inclusion criteria were included in the present review.

Between the eligibility phase and the articles included in this systematic review, some papers were excluded including the preschool studies. The main reasons for exclusion were manuscripts with individual and socioenvironmental but not school variables such as exposures, specific studies about the PE class enjoyment, papers merely describing the school environment or school-based opportunities for physical activity and frequently papers evaluating the neighborhood facilities or the route to and from schools and effects on physical activity practice.

The literature review results are summarized in two tables. In Table 1, we describe studies according to author, location and year, summarize the exposure and outcome variables, describe the sample, design and highlight main findings. In Table 2, we display details of the measurements of school environments (exposure + main dimension) and physical activity (outcomes + main measurement). This strategy was used given the wide heterogeneity in the measurement techniques 
across the reviewed studies. After this description, we provide readers with a summary of each article in the text.

Out of the 13 studies, six were conducted in the United States. Seven of them used objectively measured physical activity (accelerometry was the most common) data and in one study the outcome variable was physical fitness. Outcome variables were heterogeneous across studies, and included recess physical activity practice, extracurricular sports practice, physical activity practice within PE classes and total physical activity.

The school environment dimension more frequently evaluated was the built environment (objective measures of the built environment were more frequently observed as compared to measured of the perceived environment.). The socio/ cultural dimension was common and aspects of the physical education were evaluated in some studies.

The Early Childhood Longitudinal Study Kindergarten Cohort (ECLS-K) followed kindergarten children in the US from 1998-1999. ${ }^{9}$ School principals answered to questions on the availability of spaces for sports practice, recreation, and other school spaces. PE teachers answered questions about the number of $\mathrm{PE}$ classes and recess physical activity per week. Climate characteristics from the study area and anthropometric data from the students were also collected. Of the schools studied, $68 \%$ had gymnasiums and only $2.5 \%$ did not have playgrounds. Schools with gymnasiums offered, on average, 8.3 extra minutes of PE per week as compared with schools without gymnasiums. However, the adequacy and quality of the gymnasiums was not associated with longer PE time (Coeff=4.87, not significant) or playgrounds activity practice (Coeff $=-1.97$, not significant).

Recess physical activity was assessed among $8^{\text {th }}$ grade students from Norwegian schools. ${ }^{10}$ The evaluation of the school environment included a combination of physical characteristics, existence of physical activity promotion policies, PE classes, and physical activity practice in alternative hours. The proportion of students who were active during recess time was greater among those studying in schools with physical activity promotion policies (49\% vs. $34 \%$ ), and in schools where physical activity possibilities were also offered in alternative hours. No association was found between being active in recess time and participation in PE classes. Multilevel analysis showed that physical attributes of schools were strong predictors of recess physical activity practice $(\beta=1.24 ; \mathrm{p}<0.001)$ and interest for physical activity.

Youth from four Belgian schools ${ }^{3}$ participated in a study on the school, household and neighborhood environments and their influence on leisure-time physical activity and participation in extracurricular sports activities. Greater availability of organized activities and supervision for physical activity practice were related to higher levels of participation in extracurricular activities (in boys total model explained $28 \%$ of the variance in extracurricular physical activity and in girls $17 \%$ of the variance). Access to sports equipment was not associated with participation in extracurricular physical activity.

A study in Canada also addressed other environments in addition to the school one ${ }^{11}$ emphasizing the perceived instead of the built environment. Perception of the physical environment in terms of availability and importance explained 5 and $8 \%$, respectively, of energy expenditure. When put together in a regression model, the school environment remained associated with energy expenditure ( $\beta$ energy expenditure $=0.14)$ whereas household and neighborhood environments did not ( $\beta$ energy expenditure $=0.09$ and $\beta$ energy expenditure $=0.01$ respectively). 
Table 1 - Characteristics of the studies evaluating the association between school environments and physical activity (PA).

\begin{tabular}{|c|c|c|c|}
\hline $\begin{array}{l}\text { First author / Coun- } \\
\text { try / Year }\end{array}$ & Exposures / Outcomes & Sample/Design & Main results \\
\hline $\begin{array}{l}\text { Fernandes[6] / US } \\
\text { / } 2010\end{array}$ & $\begin{array}{l}\text { Availability and quality of PA facili- } \\
\text { ties / recess and PE }\end{array}$ & $\begin{array}{l}8,9355 \text { th grade students/ } \\
\text { Cohort }\end{array}$ & $\begin{array}{l}\text { Availability of gymnasiums was related to } 8.3 \text { ex- } \\
\text { tra minutes of PE per week. The adequacy of PA } \\
\text { facilities was not associated with PE or recess. }\end{array}$ \\
\hline $\begin{array}{l}\text { Haug[7] / Norway } \\
\text { / } 2010\end{array}$ & $\begin{array}{l}\text { School policies, physical features / } \\
\text { self-reported recess and extracur- } \\
\text { ricular PA }\end{array}$ & $\begin{array}{l}68 \text { schools and 1,347 8th } \\
\text { grade students/Cross-sec- } \\
\text { tional }\end{array}$ & $\begin{array}{l}\text { Students from schools with policies of PA pro- } \\
\text { motion and offer of extracurricular PA are more } \\
\text { active than students from schools without such } \\
\text { features }\end{array}$ \\
\hline $\begin{array}{l}\text { Haerens[2] / Bel- } \\
\text { gium / } 2009\end{array}$ & $\begin{array}{l}\text { Physical features, self-reported } \\
\text { extracurricular PA, supervision / } \\
\text { self-reported PA }\end{array}$ & $\begin{array}{l}4 \text { schools and } 5237 \text { th } \\
\text { and 8th grade students/ } \\
\text { Cross-sectional }\end{array}$ & $\begin{array}{l}\text { The higher the number of extracurricular activ- } \\
\text { ities offered, the higher the levels of PA among } \\
\text { students. Supervision was also related to higher } \\
\text { PA levels. }\end{array}$ \\
\hline $\begin{array}{l}\text { Fein[8] / Canada / } \\
2004\end{array}$ & $\begin{array}{l}\text { Perception of availability and } \\
\text { importance of physical features / } \\
\text { self-reported PA }\end{array}$ & $\begin{array}{l}4 \text { schools and } 6109 \text { th } \\
\text { to } 12 \text { th grade students/ } \\
\text { Cross-sectional }\end{array}$ & $\begin{array}{l}\text { Availability and importance of physical features } \\
\text { explained } 5 \% \text { and } 8 \% \text { of the variance in energy } \\
\text { expenditure; respectively. }\end{array}$ \\
\hline $\begin{array}{l}\text { Ridgers[11] / Unit- } \\
\text { ed Kingdom / } 2007\end{array}$ & $\begin{array}{l}\text { Playground intervention / acceler- } \\
\text { ometry and heart rate-based recess } \\
\text { PA }\end{array}$ & $\begin{array}{l}15 \text { intervention ( } 130 \text { boys, } \\
126 \text { girls) and } 11 \text { control } \\
\text { schools ( } 102 \text { boys, } 112 \\
\text { girls)/Intervention }\end{array}$ & The intervention led to increased recess PA \\
\hline $\begin{array}{l}\text { Durant[9] / United } \\
\text { States / } 2009\end{array}$ & $\begin{array}{l}\text { Days of PE per week, access to } \\
\text { equipment and pitches / self-re- } \\
\text { ported PA, television viewing and } \\
\text { obesity }\end{array}$ & $\begin{array}{l}165 \text { adolescents aged } 12- \\
18 \text { years/ Cross-sectional }\end{array}$ & $\begin{array}{l}\text { The three exposure variables were associated with } \\
\text { PA, but not with television viewing or obesity. }\end{array}$ \\
\hline $\begin{array}{l}\text { Cohen[14] / United } \\
\text { States / } 2008\end{array}$ & $\begin{array}{l}\text { Outdoor space measured by photos } \\
\text { and built area and checklist of } \\
\text { spaces and equipment / accelerom- } \\
\text { etry-based PA }\end{array}$ & $\begin{array}{l}1,566 \text { 6th grade girls/ } \\
\text { Cross-sectional }\end{array}$ & $\begin{array}{l}\text { Outdoor spaces were related to accelerome- } \\
\text { try-based PA, but part of the association was } \\
\text { explained by weather characteristics. }\end{array}$ \\
\hline $\begin{array}{l}\text { Cradock[15] / Unit- } \\
\text { ed States / } 2007\end{array}$ & $\begin{array}{l}\text { Built area and spaces for playing } \\
\text { measured by satellite photos and } \\
\text { architectonic plans / accelerome- } \\
\text { try-based physical activity }\end{array}$ & $\begin{array}{l}10 \text { schools and } 2487 \text { th- } \\
\text { and } \\
\text { 8th-grade students / } \\
\text { Cross-sectional }\end{array}$ & $\begin{array}{l}\text { Higher school areas, built areas and spaces for } \\
\text { playing were related to higher PA levels. }\end{array}$ \\
\hline $\begin{array}{l}\text { Sallis[16] / United } \\
\text { States / } 2001\end{array}$ & $\begin{array}{l}\text { Physical space, equipment and } \\
\text { supervision / observed PA }\end{array}$ & $\begin{array}{l}24 \text { schools and } 1,0816 \text { th } \\
\text { to } 8 \text { th grade students/ } \\
\text { Cross-sectional }\end{array}$ & $\begin{array}{l}\text { The school environment explained } 42 \% \text { of the } \\
\text { variance on PA among girls and } 56 \% \text { among } \\
\text { boys. }\end{array}$ \\
\hline $\begin{array}{l}\text { Nichol[10] / Canada } \\
\text { / } 2009\end{array}$ & $\begin{array}{l}\text { School policies, recreational oppor- } \\
\text { tunities, physical space / self-report- } \\
\text { ed PA }\end{array}$ & $\begin{array}{l}154 \text { schools and } 7,6386 \text { th } \\
\text { to } 10 \text { th grade students/ } \\
\text { Cross-sectional }\end{array}$ & $\begin{array}{l}\text { Offer of several activities was related to higher } \\
\text { self-reported PA. Other environmental features } \\
\text { were not associated with PA. }\end{array}$ \\
\hline $\begin{array}{l}\text { Nielsen[12] / New } \\
\text { Zealand / } 2010\end{array}$ & $\begin{array}{l}\text { Playgrounds characteristics (area } \\
\text { and number) / accelerometry-based } \\
\text { PA }\end{array}$ & $\begin{array}{l}7 \text { schools and } 417 \text { chil- } \\
\text { dren aged } 5-12 \text { years/ } \\
\text { Cross-sectional }\end{array}$ & $\begin{array}{l}\text { The number of features, but not their area, was } \\
\text { associated with accelerometry-based PA. }\end{array}$ \\
\hline $\begin{array}{l}\text { Willenberg[13] / } \\
\text { Australia / } 2010\end{array}$ & $\begin{array}{l}\text { Perception of playground charac- } \\
\text { teristics (supervision and number } \\
\text { of features) / observed PA and } \\
\text { perceptions about it }\end{array}$ & $\begin{array}{l}23 \text { schools and 3,006 } \\
\text { children aged 8-11 years/ } \\
\text { Cross-sectional }\end{array}$ & $\begin{array}{l}\text { Loose equipment and supervision were related } \\
\text { with vigorous-intensity PA in playgrounds. }\end{array}$ \\
\hline $\begin{array}{l}\text { Kelly[17] / United } \\
\text { States / } 2010\end{array}$ & $\begin{array}{l}\text { Environmental features / physical } \\
\text { fitness }\end{array}$ & $\begin{array}{l}93 \text { schools and approx- } \\
\text { imately } 50005 \text { th to } 7 \text { th } \\
\text { grade students/Cross-sec- } \\
\text { tional }\end{array}$ & $\begin{array}{l}\text { All eight environmental features were related to } \\
\text { physical fitness. }\end{array}$ \\
\hline
\end{tabular}

The association between perceived school environment and self-reported physical activity (inside and outside the school) was assessed in 12-18 year-old adolescents from three US cities. ${ }^{12}$ Access to the school in other hours than the regular ones was not associated with higher physical activity levels inside the school, 
( $\beta=1.845 ; p=0.08)$ but was significantly associated with physical activity outside the school $(\beta=0.801 ; p=0.02)$. Supervision for physical activity practice and availability of equipment and materials were not associated with activity levels.

A study in Canada ${ }^{13}$ asked school principals on school environments and students' participation in physical activity. Exposure to two hours per week or more of $\mathrm{PE}$ ranged from $14 \%$ to $92 \%$ across the schools. Most characteristics investigated did not present a significant association with physical activity within $\mathrm{PE}$ classes (for instance, good field condition shows a $\mathrm{RR}=1.04$, not significant for boys and $\mathrm{RR}=0.97$, not significant for girls). An exception was the availability of pitches, which was associated with a $29 \%$ increased physical activity level among boys. Leisure time physical activity, on the other hand, was positively related to the offer of several sports modalities at school and the existence of pitches.

An intervention study was conducted in schools located in the poorest areas of the Northwest, UK. ${ }^{14}$ Playgrounds of 15 schools were painted using three target colored areas and improvements in sports equipments took place. Control schools, matched by socioeconomic level, remained unchanged. Follow up data were collected six weeks and six months after the changes. The intervention was effective both in the short and mid-term at increasing recess physical activity (adjusted model: $\beta$ for moderate-to-vigorous physical activity $=4.53, \mathrm{p}=0.03$ and adjusted model: $\beta$ for vigorous physical activity $=2.32, \mathrm{p}=0.005$ ), measured either by accelerometry or by heart rate.

In New Zealand, playgrounds from seven schools were evaluated. ${ }^{15}$ The two main variables analyzed were area (ranged from $5014 \mathrm{~m}^{2}$ to $24,102 \mathrm{~m}^{2}$ ) and number of features (ranged from 14 to 35). Physical activity inside and outside the school was measured by accelerometry. The number of features in the playground was directly related to physical activity levels. One extra feature was related to four extra minutes of physical activity at school and nine extra minutes of physical activity per day, taking into account activities performed outside the school. Playground area, on the other hand, was not associated with physical activity level.

A combination of qualitative and quantitative methodologies ${ }^{16}$ was used to evaluate playgrounds in a low socioeconomic region in Melbourne, Australia. Physical activity was measured using the System for Observing Play and Leisure Activity in Youth (SOPLAY) in 23 schools, and in 12 of them, focal groups were used to understand the perceptions of children about the playgrounds. Participation in vigorous-intensity activities was related to supervision for physical activity (65\% vs. $52 \%)$. Focal groups suggested that very simple strategies could be effective at increasing youth's use of playgrounds, including painting the features, loose equipment and play-line markings.

Girls from year 6 took part in the Trial of Activity for Adolescent Girls (TAAG), ${ }^{17}$ an intervention aimed at reducing physical inactivity. Physical activity was measured by accelerometry and the school environment was assessed through satellite photos, built area, and a check list of spaces and equipment. A significant association between outdoor space and physical activity was observed both in the unadjusted and in the adjusted analyses, although the magnitude of the association was largely reduced after inclusion of weather in the model (attenuated from an average of 4.8 minutes to 3.9 minutes per active facility).

Cradock and colleagues ${ }^{18}$ studied the built environment and its association with physical activity. Architectonic evaluations, total area, satellite photos were used to assess the environment of 10 schools in Boston, US. Play area correspond- 
ed to $3 \%$ to $62 \%$ of the schools total area. Regression models showed that the greater the play area per student, the higher the accelerometry-based physical activity inside the school (estimate of 0.22 in physical activity).

A study with youth from 24 schools in San Diego, US evaluated the association between physical activity and the school environment. ${ }^{19}$ The regression models were able to explain $42 \%$ and $56 \%$ of the variability in physical activity inside the school among girls and boys, respectively, even using just a few environmental variables. Among girls and boys, supervision for physical activity practice was an important predictor of activity levels. Among boys only, availability of equipment was also related to physical activity levels ( $10.3 \%$ of physical activity variance).

In the state of Georgia, US, eight environmental features such as PE requirements, access to gymnasiums or pitches, community access to school's facilities were studied in relation to physical fitness. ${ }^{20}$ These variables, combined with sociodemographic characteristics, explained 30\% of the variance in aerobic fitness. This was the only study we detected on the association between school environments and physical fitness.

Table 2 - Detailed characteristics of the measures of school environment and physical activity (PA).

\begin{tabular}{|c|c|c|c|c|}
\hline $\begin{array}{l}\text { First author / } \\
\text { Country / Year }\end{array}$ & Measures of the school environment & $\begin{array}{l}\text { Main } \\
\text { dimen- } \\
\text { sion }\end{array}$ & Measures of physical activity & $\begin{array}{l}\text { Main } \\
\text { measure- } \\
\text { ment }\end{array}$ \\
\hline $\begin{array}{l}\text { Fernandes[6] / } \\
\text { US / } 2010\end{array}$ & $\begin{array}{l}\text { Availability and adequacy of gymnasiums (primary for PE } \\
\text { classes) and playgrounds (primary for recess) were evalu- } \\
\text { ated through interviews with school principals. }\end{array}$ & B & $\begin{array}{l}\text { Teachers reported number of PE classes } \\
\text { per week and recess number of days } \\
\text { and duration. }\end{array}$ & $S$ \\
\hline $\begin{array}{l}\text { Haug[7] / Nor- } \\
\text { way / } 2010\end{array}$ & $\begin{array}{l}\text { Availability of } 16 \text { physical features, existence or not of PA } \\
\text { policies, PE classes and extracurricular activities. }\end{array}$ & B & $\begin{array}{l}\text { Students reported how active they were } \\
\text { during recess time. }\end{array}$ & $\mathrm{S}$ \\
\hline $\begin{array}{l}\text { Haerens[2] } \\
\text { / Belgium / } \\
2009\end{array}$ & $\begin{array}{l}\text { The questionnaire on school environment was filled by } \\
\text { one teacher in each school. It investigated access to } \\
\text { equipment and sports materials, supervision and extracur- } \\
\text { ricular activities. }\end{array}$ & B & $\begin{array}{l}\text { The Flemish Physical Activity Question- } \\
\text { naire (FPAQ) was used to investigate } \\
\text { time spent in extracurricular activities. } \\
\text { Leisure time PA was measured by } \\
\text { self-report and a subsample of the stu- } \\
\text { dents wore accelerometers for six days. }\end{array}$ & $S$ \\
\hline $\begin{array}{l}\text { Fein }[8] \text { / Cana- } \\
\text { da / } 2004\end{array}$ & $\begin{array}{l}\text { Students' perception of availability and importance of en- } \\
\text { vironmental features was measured using a scale ranging } \\
\text { from } 0 \text { (strongly disagree) to } 10 \text { (strongly agree). }\end{array}$ & B & $\begin{array}{l}\text { The Godin leisure time PA questionnaire } \\
\text { was administered to students. Energy } \\
\text { expenditure was estimated. }\end{array}$ & $\mathrm{S}$ \\
\hline $\begin{array}{l}\text { Ridgers[11] / } \\
\text { United King- } \\
\text { dom / } 2007\end{array}$ & $\begin{array}{l}\text { Each playground was divided into three areas (red for } \\
\text { sports, blue for multiple activities and green for quiet } \\
\text { activities). }\end{array}$ & B & $\begin{array}{l}\text { All students used a heart rate mon- } \\
\text { itor and approximately half of them } \\
\text { also used an accelerometer (epoch } 5 \\
\text { seconds). }\end{array}$ & $\mathrm{O}$ \\
\hline $\begin{array}{l}\text { Durant[9] / } \\
\text { United States / } \\
2009\end{array}$ & $\begin{array}{l}\text { Data on number of PE classes per week, access to equip- } \\
\text { ment, participation in extracurricular activities, and use } \\
\text { of the school space after the school hours were collected } \\
\text { through self-report by the students. }\end{array}$ & $\begin{array}{l}\text { PE } \\
+S C \\
+B\end{array}$ & $\begin{array}{l}\text { Self-reported questionnaire about PA } \\
\text { practice inside and outside the school in } \\
\text { the past week and in a typical week. }\end{array}$ & $S$ \\
\hline $\begin{array}{l}\text { Cohen[14] / } \\
\text { United States / } \\
2008\end{array}$ & $\begin{array}{l}\text { Satellite photos were used to estimate built area (con- } \\
\text { sidering the first floor), and a checklist on school spaces, } \\
\text { such as gymnasiums and sports courts. }\end{array}$ & B & $\begin{array}{l}\text { Girls used an Actigraph accelerometer } \\
\text { for six consecutive days, including two } \\
\text { weekend days. }\end{array}$ & $\mathrm{O}$ \\
\hline $\begin{array}{l}\text { Cradock[15] / } \\
\text { United States } \\
\text { / } 2007\end{array}$ & $\begin{array}{l}\text { Objective measures using ortho-photos, architectonic } \\
\text { plans and ArcGIS }\end{array}$ & B & $\begin{array}{l}\text { Students used a TriTrac-R3D accelerom- } \\
\text { eter for four consecutive days. }\end{array}$ & $\mathrm{O}$ \\
\hline $\begin{array}{l}\text { Sallis[16] / } \\
\text { United States / } \\
2001\end{array}$ & $\begin{array}{l}\text { The type of the area (indoor, outdoor) and its size were } \\
\text { evaluated. The existence of supervision and equipment } \\
\text { was assessed by observation. }\end{array}$ & B & $\begin{array}{l}\text { SOPLAY was used before the school, } \\
\text { during lunch time and after school. }\end{array}$ & $\mathrm{O}$ \\
\hline
\end{tabular}




\begin{tabular}{|c|c|c|c|c|}
\hline $\begin{array}{l}\text { First author / } \\
\text { Country / Year }\end{array}$ & Measures of the school environment & $\begin{array}{l}\text { Main } \\
\text { dimen- } \\
\text { sion }\end{array}$ & Measures of physical activity & $\begin{array}{l}\text { Main } \\
\text { measure- } \\
\text { ment }\end{array}$ \\
\hline $\begin{array}{l}\text { Nichol[10] / } \\
\text { Canada / } 2009\end{array}$ & $\begin{array}{l}\text { The school principal and vice principal answered a ques- } \\
\text { tionnaire about the size of the school, its programs and } \\
\text { activities, availability and condition of the physical spaces, } \\
\text { and types of sports activities offered to students. }\end{array}$ & $B+S C$ & $\begin{array}{l}\text { Students reported the activities carried } \\
\text { out at school during PE classes and in } \\
\text { other periods. }\end{array}$ & $\mathrm{S}$ \\
\hline $\begin{array}{l}\text { Nielsen[12] / } \\
\text { New Zealand / } \\
2010\end{array}$ & $\begin{array}{l}\text { Playgrounds were evaluated according to size and number } \\
\text { of features through observation. }\end{array}$ & B & $\begin{array}{l}\text { Students used a Mini-Mitter (Bend, OR) } \\
\text { accelerometer (epoch } 15 \text { seconds) for } 2 \\
\text { to } 5 \text { days. }\end{array}$ & $\mathrm{O}$ \\
\hline $\begin{array}{l}\text { Willenberg[13] } \\
\text { / Australia / } \\
2010\end{array}$ & $\begin{array}{l}\text { Spaces were documented through photos and classified } \\
\text { by type of surface and equipment. Supervision and avail- } \\
\text { ability of equipment were observed. }\end{array}$ & B & $\begin{array}{l}\text { SOPLAY was used to assess PA. Obser- } \\
\text { vations took place in non-rainy days. } \\
\text { Playgrounds were observed in lunch } \\
\text { time. }\end{array}$ & $\mathrm{O}$ \\
\hline $\begin{array}{l}\text { Kelly[17] / } \\
\text { United States } \\
\text { / } 2010\end{array}$ & $\begin{array}{l}\text { PE and environmental items were evaluated: duration of } \\
\text { classes, gymnasiums, fields, access of the community to } \\
\text { the school, sports opportunities offered for students. }\end{array}$ & $B+P E$ & $\begin{array}{l}\text { The Progressive Aerobic Cardiovascular } \\
\text { Endurance Run (PACER), the Modified } \\
\text { Pull-Up, the Curl-Up, the Back-Saver } \\
\text { Sit and Reach and the Trunk Lift tests } \\
\text { were used. }\end{array}$ & $\mathrm{O}$ \\
\hline
\end{tabular}

B: built, SC: social/cultural, I: informational, N: natural and PE: physical education (third column), S: subjective and O: objective (fifth column)

\section{DISCUSSION}

The number and methodological quality of studies on the association between school environment and physical activity are growing. All studies included in the present review were published after the year $2000{ }^{19}$. A recent narrative review ${ }^{4}$ summarized studies on the influence of child care policy and environment on pre-school children's physical activity, showing that some environmental features, such as green areas, playgrounds, are related to physical activity levels among preschool children. The current study adds to the literature by providing a systematic review of articles involving the school environment and physical activity, covering elementary and high schools.

The definition of the school environment is not rigid and the interaction between physical dimensions, sociocultural factors, informational features and natural aspects should be highlighted. Rarely one single study evaluates only one of these features alone, but often studies on the built environment arena still apply subjective measures of the environment. Factors such as school policies and PE importance within schools are often included in studies in this field ${ }^{2}$. In summary the results focus on features of the physical environment, ${ }^{18}$ others analyze variables such as school policies, PE classes, extracurricular activities, among others ${ }^{3}$. Another important distinction is between perceived and built environmental attributes: some studies emphasized the perception of students, teachers or school principals about the school environment ${ }^{9}$ and others addressed features of the built environment, such as the number of features in playgrounds and school area $\left(\mathrm{m}^{2}\right) .{ }^{17}$

In several studies, the evaluation of physical activity was restricted to the period children spend at school. From a public health perspective, not only activities performed at school are relevant, and therefore, the evaluation of total physical activity is recommended for future studies. This is essential for addressing the possibility of short and long-lasting changes in behavior related to exposure to different school environments. Few articles so far have combined information on school environments and social support, mainly from parents and peers, at determining physical activity levels. Such approach seems essential for improving our 
understanding on children and adolescents behavior. Additionally, as mentioned by others, ${ }^{3}$ studies evaluating the effects of school, household and neighborhood environments on physical activity are required, because children spend most of their days in one of these three places. Around $50 \%$ of the studies reviewed used some objective measure of physical activity, suggesting improvements in the area of physical activity measurement. However, one should not abandon the subjective measurements, because those are able to provide us with some context about the activities that children and adolescents actually do. Although this would potentially make studies more complex in terms of logistics, it would help researchers understand the influence of different environment-related attributes on various manifestations of physical activity in depth. From the current literature, we are also unable to evaluate whether the school environments influences objective or self-reported physical activity more strongly.

Studies with children from grades 1 to 4 are rare in the literature. The review by Trost and colleagues ${ }^{4}$ detected a series of studies with preschool children, while in the present review, most studies identified were conducted with children and adolescents from $5^{\text {th }}$ grade onwards. This gap needs to be addressed because years 1 to 4 are crucial in terms of children's development, being in the process of 'building' their long-lasting behaviours. In addition, children in grades 1 to 4 are highly active, ${ }^{21}$ and understanding the reasons for that is as important or even more important than understanding the determinants of the well-known declines in physical activity levels at later ages ${ }^{22}$.

Some limitations of our review should be considered. First, the lack of precision in the concept of school environment may have led us to miss a few relevant studies based on the keywords we chose. Evaluating reference lists of relevant articles was a strategy we adopted in order to minimize the impact of this limitation. The fact that most studies are relatively new makes it impossible for us to drawn definitive conclusions about the topic; further studies are needed. We highlight here that the methodologies employed in the existing studies are greatly heterogeneous, so that attempts for creating standardized instruments in the field are welcome. Due to the heterogeneity across studies, it was also impossible to summarize their results through any meta-analytical approach.

We chose to restrict our review to Pubmed articles, based on the fact that most studies in the field were published in such database. However, we acknowledge that some studies may have not been detected due to this methodological decision. We did not include articles published in non-indexed journals due to the logistic difficulty in finding them. A methodological approach for future systematic reviews to update this information, or to expand to other environment settings, could be the complementation of the search in other databases, contact with authors and examination of selected journals table of contents. The search in other database, even producing duplicates, would strengthen the capture of the main work of the school environment effects on physical activity. A limitation of this review was the lack of quantitative characterization studies excluded in the eligibility phase and incorporated after reading the lists of references. In an attempt to minimize this problem, some types of approach, considered out of the sphere of this review, were described in the results section.

One of the main characteristics of the studies included in our review is the heterogeneity of measures of both the exposure (school environment) and outcome (physical activity), thus limiting our ability to compare studies. Several in- 
struments were created specifically for a single study and have not been submitted to validation studies. The sources of data also vary considerably across studies, including interviews with school teachers and principals, check lists on school environmental attributes, among others. In studies including interviews with teachers, but particularly with principals, information bias is a concern, given the fact that subjects might avoid negative answers. Objective measures are needed to help fill this gap. The lack of prospective studies is a key literature gap. Several studies relied on cross-sectional snapshots of existing prospective studies. Longitudinal analyses will help the field understand how changes in school environments influence physical activity behaviors. Intervention studies are therefore a priority for the near future. The combination of qualitative and quantitative methods is also warranted, as done in the study by Willenberg et al. ${ }^{16}$ Qualitative data may help understand why some attributes of the school environment are more important than others at determining children and adolescents' behaviors.

Although the field is still in its 'infancy', ${ }^{23}$ studies on the school environment are particularly relevant given its direct applicability for the planning of health promotion interventions. However, both the studies on this topic and interventions designed based on their results need to take into account cultural specificities of each population and functional school environment characteristics; children from different socioeconomic backgrounds may respond differently to school environment features. Therefore, no intervention will be effective in every setting.

In summary, no definitive conclusion about the influence of school environmental on children and adolescent physical activity can be drawn from the current literature due to the heterogeneity across studies and the lack of prospective data (out of 13 studies, 11 were cross-sectional). However, several individual features of the school environment appear to be associated with increased physical activity among children and adolescents. Improvements in playgrounds, such as painting and improving physical spaces,; the supervision of physical education teachers; the creation of health promotion policies at school, covering physical activity actions inside and outside the physical education classes; and positive perceptions of the environment by students are likely to positively influence physical activity patterns of children and adolescents.

\section{Authors' contributions}

Alan G Knuth carried out the literature search and data extraction. Pedro C Hallal was responsible for providing a second evaluation in the case of doubts. Both authors took part in the writing and approved the final version of this manuscript.

\section{REFERENCES}

1. Sallis JF, Bauman A, Pratt M. Environmental and policy interventions to promote physical activity. Am J Prev Med. 1998 Nov;15(4):379-97.

2. Sallis J, Cervero R, Ascher W, et al. An ecological approach to creating active living communities. Annu Rev Public Health. 2006;27:297-322.

3. Haerens L, Craeynest M, Deforche B, et al. The Contribution of Home, Neighbourhood and School Environmental Factors in Explaining Physical Activity among Adolescents. J Environm Public Health. 2009;2009:320372.

4. Trost SG, Ward DS, Senso M. Effects of child care policy and evironment on physical activity. Med Sci Sports Exer. 2010;42(3):520-5.

5. Jones SE, Fisher CJ, Greene BZ, et al. Healthy and Safe School Environment, Part I: Results From the School Health Policies and Programs Study 2006.J School Health. 2007;77(8):522-43. 
6. BRASIL. Pesquisa Nacional de Saúde do Escolar (PENSE). IBGE. Rio de Janeiro, 2009.

7. Hino A, Reis R, Florindo A. Ambiente construído e atividade física: uma breve revisão dos métodos de avaliação. Rev Bras Cineantropom Desempenho Hum. 2010;12(5):387-94.

8. Moher D, Liberati A, Tetzlaff J, Altman DG. Preferred reporting items for systematic reviews and meta-analyses: the PRISMA statement. J Clin Epidemiol. 2009 Oct;62(10):1006-12.

9. Fernandes M, Sturm R. Facility provision in elementary schools: correlates with physical education, recess, and obesity. Prev Med. 2010 Jan;50 Suppl 1:S30-5.

10. Haug E, Torsheim T, Samdal O. Local school policies increase physical activity in Norwegian secondary schools. Health Prom Int. 2010 Mar;25(1):63-72.

11. Fein AJ, Plotnikoff RC, Wild TC, Spence JC. Perceived environment and physical activity in youth. Int J Behav Med. 2004;11(3):135-42.

12. Durant N, Harris SK, Doyle S, et al. Relation of school environment and policy to adolescent physical activity. J School Health. 2009 Apr;79(4):153-9; quiz 205-6.

13. Nichol ME, Pickett W, Janssen I. Associations between school recreational environments and physical activity. J School Health. 2009 Jun;79(6):247-54.

14. Ridgers ND, Stratton G, Fairclough SJ, Twisk JW. Long-term effects of a playground markings and physical structures on children's recess physical activity levels. Prev Med. 2007 May;44(5):393-7.

15. Nielsen G, Taylor R, Williams S, Mann J. Permanent play facilities in school playgrounds as a determinant of children's activity. J Phys Act Health. 2010 Jul;7(4):490-6.

16. Willenberg L, Ashbolt R, Holland D, et al. Increasing school playground physical activity: A mixed methods study combining environmental measures and children's perspectives. J Science Med Sport. 2010;13:210-6.

17. Cohen D, Scott M, Wang FZ, et al. School design and physical activity among middle school girls. J Phys Act Health. 2008 Sep;5(5):719-31.

18. Cradock AL, Melly SJ, Allen JG, et al. Characteristics of school campuses and physical activity among youth. Am J Prev Med. 2007 Aug;33(2):106-13.

19. Sallis JF, Conway TL, Prochaska JJ, et al. The association of school environments with youth physical activity. Am J Public Health. 2001 Apr;91(4):618-20.

20. Kelly I, Phillips M, Revels M, Ujamaa D. Contribution of the school environment to physical fitness in children and youth. J Phys Act Health2010;7:333-42.

21. Corbin CB, Pangrazi RP, Le Masurier GC. Physical activity for children: current patterns and guidelines. J Phys Act Health. 2004;1(281).

22. Dumith S, Gigante D, Rodrigues M, Kohl H. Physical activity change during adolescence: a systematic review and a pooled analysis. Int J Epidemiol. 2011;40:685-98.

23. Story M, Giles-Corti B, Yaroch AL, et al. Work group IV: Future directions for measures of the food and physical activity environments. Am J Prev Med. 2009 Apr;36(4 Suppl):S182-8.

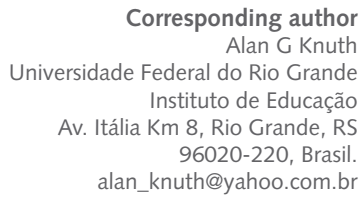

